\title{
Cosmopolitan Islamic Identity and Thought
}

The Association of Muslim Social Scientists (AMSS) held its Third Annual Canadian Regional Conference on "Cosmopolitan Islamic Identity and Thought" on 24 November 2007 at Wilfrid Laurier University (Waterloo, ON). Opening the event with her keynote address, "Consumption and Cosmopolitanism: The Veil, The Body, The Law," Reina Lewis (University of East London) pointed out that in British culture, cosmopolitanism has not yet appropriated the Muslim veil as a desirable object of fashion consumption for the majority society, although Muslim women have appropriated and indigenized some western fashions. However, this does not prevent the majority society from making interpretive "readings" of the veil relative to dominant fashion cultures and participating in neo-Orientalist discourses. Despite the (shockingly) recent British legislation of 2003 that finally explicitly forbids religious discrimination, some recent prominent public discourse on the veil in Britain has turned its attention to the issue of face veiling as a potentially insidious fashion practice, arguing essentially (and uncritically) that visibility is equal to transparency, integrity, and truth.

The first presentations began with concurrent panels on "Exegetes and Mystics" and "Orientialism and Media." Asma Afsaruddin (University of Notre Dame) began the first one with "Finding the Golden Mean: Qur' anic Discourses on Moderation and Pluralism," in which she documented two readings of the Qur'an on middle or moderate community, based on Qur'an 2:143 and 5:66, both historically and currently. One reading, which she termed supercessionist, interprets moderate community to include only Muslims. However, another reading is more ecumenical in that moderate community may also include moderate peoples of all Abrahamic religions. Afsaruddin points to the latter reading as being potentially very useful to Muslims in today's increasingly plural and cosmopolitan societies. Husein Khimjee (University of Toronto) argued, in "Bases for Cosmopolitan Identification in the Qur' an and Sunnah," that a theoretical and practical model for a plural Muslim society was established right after the hijrah, when Jews and Christians were invited to become part of a "multi-cultural" society, and was developed further in the Ottoman millet system. Remi Warner (York University) spoke on "The Other in The Light of the One: An Islamic/Sufic Perspective on the Sacred Depth/Value of Diversity and Dialogue." Warner stated that Shah-Kazemi's Ibn Arabi-influenced interpretation of tawhid, which takes the moment of divine self-disclosure as an image that meta- 
physically affirms diversity and dialogue among peoples, might be useful as an Islamic model for cosmopolitan societies.

The other panel began with Yasmin Jiwani's (Concordia University) "Colluding Hegemonies: Constructing the Muslim Other post 9/11." She analyzed media representations of Muslims in two major Canadian daily newspapers: the Globe and Mail and the National Post. Although they normally present different political orientations, she said they colluded in presenting a homogenous, racialized, and gendered portrayal of the Muslim “Other" immediately after 9/11. Junaid Quadri (McGill University) followed with "Anticipating Orientalism: An Examination of Indigenous Critiques of Istishraq in the Pakistani Monthly al-Bayyinat." Mentioning how Edward Said gave credit to others for his ideas on Orientialism, but only referred to scholars who shared his western intellectual tradition, Quadri stated that alBayyinat's indigenous critiques preceded Said's and did not rely on western intellectual traditions. Daniel Ahadi's (Simon Fraser University) "Internet and Democracy: Challenges Facing Iran" asked if the Internet fosters democracy or reinforces existing hegemonies. He acknowledged the Internet's democracy-building potential, but said it has not fostered democracy in Iran due to strict government regulations, existing economic and cultural structures, and the users' broad embrace of the technology's commercial logic. Usamah Ansari (York University) delivered "Lucknow Ki Sar-Zameen (Lucknow from Head to Toe): Performative Citations that Produce 'Muslimness' in South Asian Cinema." Ansari explained how "Muslimness" is performed in Bollywood cinema to imply decay and decadence, suggesting that Muslims are "Other" to the Hindu-based national project. However, he said, the "Other's" presence might constitute a point of alterity that is open to Muslim subjectivity being performed in a way that disrupts the more hegemonic national vision now dominant in South Asian cinema.

Miriam Cooke (Duke University), in her keynote address "Muslimwoman Cosmopolitanism," lamented that the Muslimwoman Cosmopolitan has to navigate her way between neo-Orientalist discourse and Islamist visions of feminine subjectivity. However, she argued that the growing industry of "insider Muslimwoman narratives" in the West (e.g., Irshad Manji, Azar Nafisi, and Ayaan Hirsi Ali) are "soft weapons" that limit potential options for genuine Muslimwoman Cosmopolitan subjectivities because of their tacit neo-Orientalist leanings.

The afternoon featured concurrent panels on "Feminist Engagements" and "Modalities of Transnational Social and Political Control." The first panel began with Roksana Bahramitash's (University of Montreal) "Iranian Islamic Women as 'the Other': A Class Analysis of the Role of Women in the 
Informal Economy and Islamic Micro Credit." Bahramitash pointed out that the West's focus on the veil, Islamic law, and gender discrimination ignores issues of female employment and economy. She cited new research on the immense importance of low-income Muslim women in Iran's informal economy who are helping themselves and others to survive financially with micro-credit programs administered by local Islamic organizations. Basharat Tayyab (University of Guelph) called for interpreting the veil as a metaphor for Jacques Derrida's differance in an attempt to bridge the gap between Muslim feminist discourse and the French feminist theory of Helene Cixous and Luce Irigaray in "Problematizing the Muslim Veil." Amina Jamal's (Ryerson University) "Modernity as Islamic Practice: Women's Selfconstruction in the Jama at-e-Islami of Pakistan," held that middle-class Pakistani women involved with the Jama'at-e-Islami, although they too are catalysts of modernity, are navigating an alternative modernity that charts a middle way between the restrictive practices of many Muslim groups and the ultra-modern ruling classes. Itrath Syed (University of British Columbia) used her "Towards an Autonomous Muslim Feminist Praxis" to show that Muslim feminists still must negotiate their work among western racialized discourses on Muslims; dominant patriarchal readings of Islam among Islamists; and western feminist readings of Muslim women as passive, infantilized, and in need of rescue. She attempted to outline the essential elements of an Islamic feminism that works toward greater equality without being co-opted into western discourses of empire.

The concurrent panel was inaugurated by Alireza Asgharsadeh's (York University) "Managing Multiple Identities in a Globalizing World: The Case of Azerbaijani Muslims," which documented the diversity of culture and experiences between Azerbaijani Muslims at home and abroad. But despite the challenges of emergent multiple identities, globalizing environments, and intercultural communications, he argued that these diverse persons share a common democratic identity. Jalal Dehzani (Carleton University) discussed, in his "Collective Identity in Islam and the Kurdish Case before and after Modernity," the "othering" deployed by Iran, Iraq, and Turkey (at times colluded in by external powers) against their Kurdish minorities. So far, according to him, the Kurds have failed to defeat these "nihilistic ideologies." In "Global Restructuring in Turkey and Political Islam," Sabine Dreher (York University) opined that the Kemalist elite, historically associated with modernization and westernization, has retreated into authoritarian nationalism while political Islam in Turkey, although associated with traditionalism and anti-modernism, is driving toward global economic integration and westernization in line with neoliberalism or the aims of the "Washington Consensus." 
Abdurrahman Beggar (Wilfrid Laurier University) focused on the concentration camps set up by France during the Algerian war in his "Camps and Social Control during the War of Algeria (1954-62)." Although allegedly justified as prisons for minority opponents, they actually detained a large segment of the population and were meant to restructure Algerian society and integrate its peoples into the French capitalist colonial project.

Ali Hasan Zaidi (Wilfrid Laurier University) opened the "Challenging Colonialism and Nationalism" panel. In his "Muslims and the Secularization of Canada," he stated that Canadian Muslims are inadvertently contributing to secularization by adopting rights-based mechanisms that tacitly deploy a secular approach to religion, and by implicitly reducing Islam's universal vision to a subordinate matter of identity politics. In "Un-Racing the Space of the Nation: The Anti-Terrorism Act and the Rhetoric of National Security," Shaista Patel (OISE, University of Toronto) called for disrupting the liberal discourse of civil liberties verses national security, which frames Canada's Anti-Terrorism Act, by exposing how its gendering and racializing of Canada's male Muslims of color jeopardizes their treatment as legitimate Canadian citizens. In his "The Role of the Critically Engaged Muslim Intellectual," Junaid S. Ahmad (College of William and Mary) critiqued simplistic attempts to translate the western narrative of democracy and human rights into the language of Islam and called for a genuine dialogue of equals. Such a dialogue can only take place, he asserted, if Muslim intellectuals pursue greater engagement with emerging Muslim social movements.

The other panel session focused on "Islam in Dialogue." In "Ethics and Nominalism in the Late Medieval Christian and Islamic Worlds: A Comparison of Ibn Taymiyya and William of Ockam," Ovamir Anjum (University of Wisconsin-Madison) compared these two contemporary and significant intellectual figures who struggled with Aristotelian realism and "right reason" and generated remarkably similar critiques and conclusions. Zulfikar Hirji (York University) showed, in "Cosmopolitanism, Islam, and Empire on the Western Indian Ocean: The Case of Sheikh-Sir Mbarak Al-Hinawy (1896-1959)," how Al-Hinawy, governor of East Africa based in Mombasa, was a Muslim cosmopolitan in the way he studied and governed local cultural diversity in concert with other Muslim and British scholars. All presentations led to engaging and protracted discussions, signaling their quality and currency. 